\section{THE WORLD TODAY}

The monthly journal of the Royal Institute of International Affairs provides the general reader with up-to-date and authoritative information on current world problems

Recent numbers include articles on:

THE NEGOTIATIONS

IN BRUSSELS: AN ITALIAN VIEW by Pietro Quaroni CAN URANIUM ENRICHMENT ENRICH SOUTH AFRICA?

by Aldo Cassuto

PALESTINIAN NATIONALISM AND THE JORDANIAN STATE by Neville Brown SINO-AMERICAN RELATIONS AFTER CAMBODIA by J.H. Kalicki

SOVIET STRATEGIC POLICY

by Malcolm Mackintosh

Annual Subscription: 65s (U.S.A. and Canada $\$ 10.00$ ) 5s. $6 d$. or $27 \frac{1}{2}$ p. per issue

Orders may be sent to booksellers and newsagents, or to the

Oxford University Press Press Road, Neasden London, N.W.10 (Tel. 01-450 8080)
Party

\section{Leadership and Revolutionary Power in China}

Edited by JOHN WILSON LEWIS

'The impact of a volume such as this which throws timidity to the wind and wrestles with the enigmas of contemporary China is refreshing.'

Far Eastern Economic Review

Twelve scholars from Britain and the United States examine Communist party politics as they evolved before the Communist takeover in 1949.

The first book in an important new series, the Contemporary China Institute Publications.

Paperback 25s. net Cloth $£ 4$ net

\section{Elites in South Asia}

Edited by E. R. LEACH and S. N. MUKHERJEE

A collection of eleven papers on elitist behaviour particularly in India during and after British rule. The authors consider who the men at the top were, how they got there and their relationship with the British.

75s. net

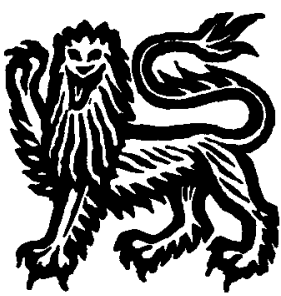

CAMBRIDGE UNIVERSITY PRESS 


\section{Journal of Social Issues}

\section{Summer 1970 Volume XXVI Number 3}

Professionals and the Poor

Issue Editor: Marcia Guttentag

Preface

Government Policy and the Poor: Past, Present and Future Introduction. Wilbur J. Cohen The More Things Change-

A Case History of Child Guidance Clinics.................Murray Levine and Adeline Levine Poor People and the Distribution of Job Opportunities....................Marcia Freedman Legal Problems Peculiar to the Poor....................................... Geoffrey C. Hazard

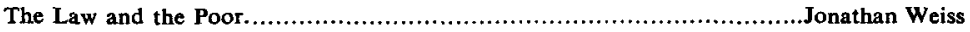
Urban School Politics: Professionalism vs, Reform..........................Marylin Gittell The Poverty Boards:

Some Consequences of "Maximum Feasible Participation" Louis A. Zurcher, Jr. Social Stereotypes and Social Research.. ...Elizabeth Herzog Black Families and White Social Science.. Andrew Billingsley

Biographical Sketches Abstracts

Order from:

Journal of Social Issues

P.O. Box 1248

Ann Arbor, Michigan 48106

1971 ANNUAL SUBSCRIPTIONS RATES INSTITUTIONS

INDIVIDUALS

SINGLE COPIES

$\$ 15.00$

Published Quarterly by

THE SOCIETY FOR THE PSYCHOLOGICAL STUDY OF SOCIAL ISSUES

(a division of the American Psychological Association)

\section{The Journal of}
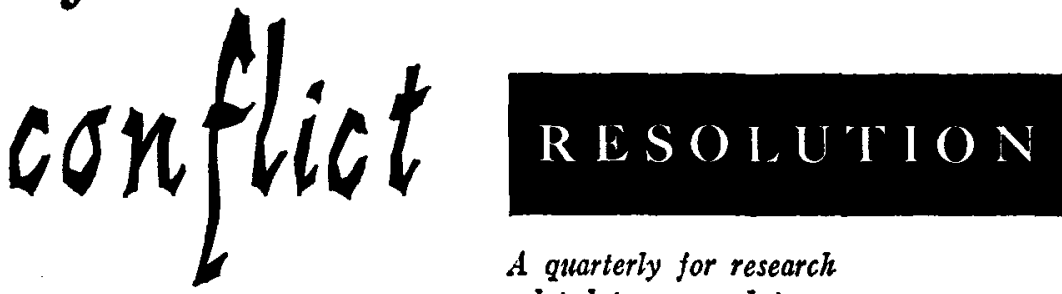

A quarterly for research

related to war and peace

SEPTEMBER 1970 (XIV, 3):

Individual Differences in "Definition of the Situation" ......... Ole R. Holsti

Attitudes toward Westbound Refugees in the

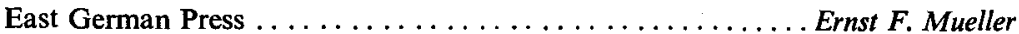

Models of Cooperation and Conflict : A Critical Review ..........Martin Patchen

Other articles; gaming section.

$\$ 8.00$ per year for individuals, $\$ 15.00$ for institutions; single issues $\$ 3.00$

Published by The Center for Research on Conflict Resolution

The University of Michigan, Ann Arbor, Michigan 48104 


\section{$A \mathbb{N} \mathbb{A} \| \mathbb{E S}$ Economies-Sociétés-Civilisations}

Revue bimestrielle, fondée en 1929 par Lucien FEBVRE et Marc BLOCH

Comité de Direction: Fernand BRAUDEL, Marc FERRO, Georges FRIEDMANN, Jacques LE GOFF, Emmanuel LE ROY LADURIE, Charles MORAZE

Secrétaire du Comité: Paul LEUILLIOT Secrétaire de la Rédaction: André BURGUIERE

25e ANNEE- $\mathrm{N}^{\circ} .5$

C. NICOLET

A. CHASTAGNOL

J. SUBLET

M. I. FINLEY

P. VIDAL-NAQUET

S. PEMBROKE

J. P. DARMON

J. BERQUE

J. SADAN

D. BAYON
SEPTEMBRE-OCTOBRE 1970

Prosopographie et histoire sociale: Rome et l'Italie.

La prosopographie, méthode de recherche sur l'histoire du Bas Empire.

La prosopographie arabe.

L'aliénabilité de la terre dans la Grèce ancienne Valeurs religieuses et mythiques de la terre et du sacrifice dans l'Odyssee.

Femmes et enfants dans les fondations de Locres et de Tarente.

Problèmes de la guerre dans la Grèce ancienne.

COMPTES RENDUS: Histoire ancienne

Les Hilaliens repentis ou L'Algérie rurale au XVe siècle d'après un manuscrit jurisprudentiel. Eléments bédouins et sédentaires dans la civilisation califienne.

Un problème de filiation architecturale: la cathédrale de Puno.

COMPTES RENDUS: Des idées et des arts

R. CAMERON

P. SOUYRI

E. LE ROY LADURIE

M. DEMBINSKA

L. GENICOT
L’Economie française: passé, présent, avenir. Aspects du marxisme aujourd'hui.

Pour une histoire de l'environnement: la part du climat.

La paléobotanique, science auxiliaire de l'histoire.

Campagnes et paysans de Picardie jusqu'au XIIIe siècle.

Redaction: 54, Boulevard Raspail-Paris VIe (222-23-49)

Administration: Librairie Armand COLIN, I03 Boulevard Saint Michel-Paris Ve Comptes Chèques Postaux: PARIS, $\mathrm{N}^{\circ} 21$ 335-25

Abonnements: France et Union Française : $36 \mathrm{~F}$. Etranger : $45 \mathrm{~F}$.

Le numéro: $7 \mathrm{~F}$. -Numéros spéciaux: $14 \mathrm{~F}$. 


\section{SURVEY}

\section{A Journal of Soviet and East European Studies}

No. 76

Summer 1970

Soviet Foreign Policy

Adam Ulam Elizabeth Valkenier

Western Foreign Policies

Elliot Goodman Robert Legvold

The Second World War

Maury Lisann Mary Dau

Ewald Osers $\quad$ Andrzej Korbonski

\section{Rumania}

Lloyd Jordan Anthony Stuart

Views and Reviews

Gerhard Ritter John Keep

Documents-Soviet Union and Czechoslovakia

Annual subscription $£ 2$ or $\$ 6$

Single issue: ros. or $\$ 1.50$

Editorial office: Ilford House, I 33 Oxford Street, London W. I.

Subscription office: Research Publications, i I Nelson Road, London S.E. I o. 


\section{Estudios \\ Internacionales}

\section{REVISTA DEL INSTITUTO DE ESTUDIOS INTERNACIONALES DE LA UNIVERSIDAD DE CHILE}

\section{Director: DANIEL MOORE}

Consejo de Redacción: Alain Joxe, Darcy Ribeiro, Osvaldo Sunkel, Claudio Véliz

\section{SUMARIO}

Alain Joxo y Cecilia Cadona Armamentismo dependiente: caso latinoamericano

Cornelius F. Murphy, Jr. Coacción económica y Tratalos desiguales

John Gittings La nueva guerra on Indochina

Claes Croner Estudios sobre el subdesarrollo colombiano, Comentario crítico

Julio Luna El desarrollo pesquere y la integración regional

Alfredo Luna Tovar La Declaración de Santiago, antecedentes y proyecciones

Reseña de libros

Libros recibidos

$\begin{array}{lll}\text { Suscripción anual: } & \text { en América Latina } & \text { US } \$ 10.00 \\ & \text { fuera de América Latina } & \text { US } \$ 13.00\end{array}$

\section{Dirigirse a: ESTUDIOS INTERNACIONALES}

Departamento de suscripciones

Cassilla I4187, Correo 2r,

Santiago de Chile 


\section{MINER VA}

A REVIEW OF SCIENCE, LEARNING AND POLICY EDITOR: EDWARD SHILS

VOLUME VIII, No. 4 OCTOBER 1970

EDITORIAL

The Political University and Academic Freedom

ARTICLES

Sponsored Research and University Budgets: A Case Study in American University Government

Frederick Betz and Carlos Kruytbosch

Bombay Colleges

Philip G. Altbach

American University Teachers and Opposition to the Vietnam War Everett Carll Ladd

Scientific Organisation and Science Policy in Imperial Germany, 18711914: The Foundation of the Imperial Institute of Physics and Technology

Frank Pfetsch

REPORTS AND DOCUMENTS

University Reform in Japan

CORRESPONDENCE

Letters from Eric Hutchinson, Jacques Waardenburg and Terry N. Clark BOOK REVIEWS

Reviews by Austen Albu, Hugh Thomas, Edmund Ions and Edward Shils CONTRIBUTORS

Single Copy $15 \mathrm{~s} . \$ 2.00$

Annual Subscription $£ 210 \mathrm{~s} / \$ 7.50$

Minerva, 4, Little Essex Street, London W.C.2: 
Comparative Studies in Society and History is a forum for presentation and discussion of new research into problems of change and stability that recur in human societies through time or in the contemporary world. It sets up a working alliance between specialists in all branches of the social sciences and humanities. Debate and review articles bring the general reader in touch with current findings and issues.

\section{NOTES FOR CONTRIBUTORS}

Contributions may be descriptive, analytical or theoretical. Any article not in itself comparative may be accepted if it lends itself to comment that will place it in comparative perspective. Correspondence with the editors prior to the submission of articles will help to enable them to obtain such comment or a companion study. Emphasis in comparative studies may be either on similarities or, if these are significant enough and call for some recasting of generalisations, on differences. All contributions and editorial correspondence should be sent to the Editors, Comparative Studies in Society and History, Department of History, University of Michigan, Ann Arbor, Michigan 48104.

Two copies of each contribution, preferably accompanied by a stamped, addressed envelope, should be submitted. Both text and footnotes should be clearly typed with double spacing and wide margins; footnotes should appear on separate pages at the end of the article. Illustrations may be included by arrangement with the editors.

Contributors will receive 50 offprints bound in the journal covers. Any additional offprints must be ordered on receipt of the first proof. 


\section{COMPARATIVE STUDIES IN SOCIETY AND HISTORY}

Editorial Foreword

\section{Cartooning}

Afaf Lutfi Al-Sayyid Marsot The Cartoon in Egypt 2-15

\section{Legal Change in Islam}

J. N. D. Anderson The Role of Personal Statutes in Social Development in Islam

\section{Conflict}

Amal Vinogradov and John Waterbury Situations of Contested Legitimacy in Morocco: An Alternative Framework

Charles Tilly and Edward Shorter The Shape of Strikes in France, 1830-1960

LEO KUPER Theories of Revolution and Race Relations

Review Article

R. R. PALMER Some Recent Work on Higher Education

\section{Cambridge University Press}

Bentley House, 200 Euston Road, London, N.W.1

American Branch: 32 East 57th Street, New York, N.Y. 10022

$£ 1$ net in U.K.; $\$ 3.00$ in U.S.A.

Subscription price $£ 3$ net in U.K.; $\$ 8.50$ in U.S.A.

Printed in Great Britain by Alden \& Mowbray Ltd at the Alden Press, Oxford 